
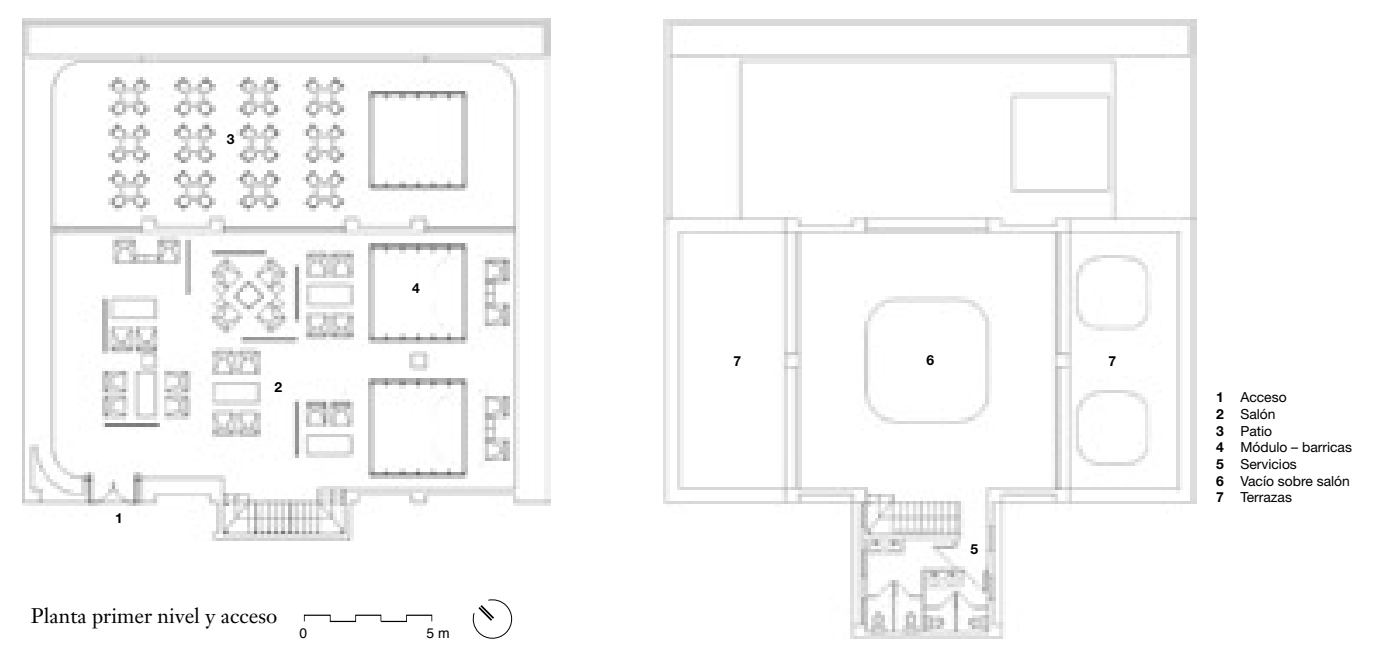

Planta segundo nivel
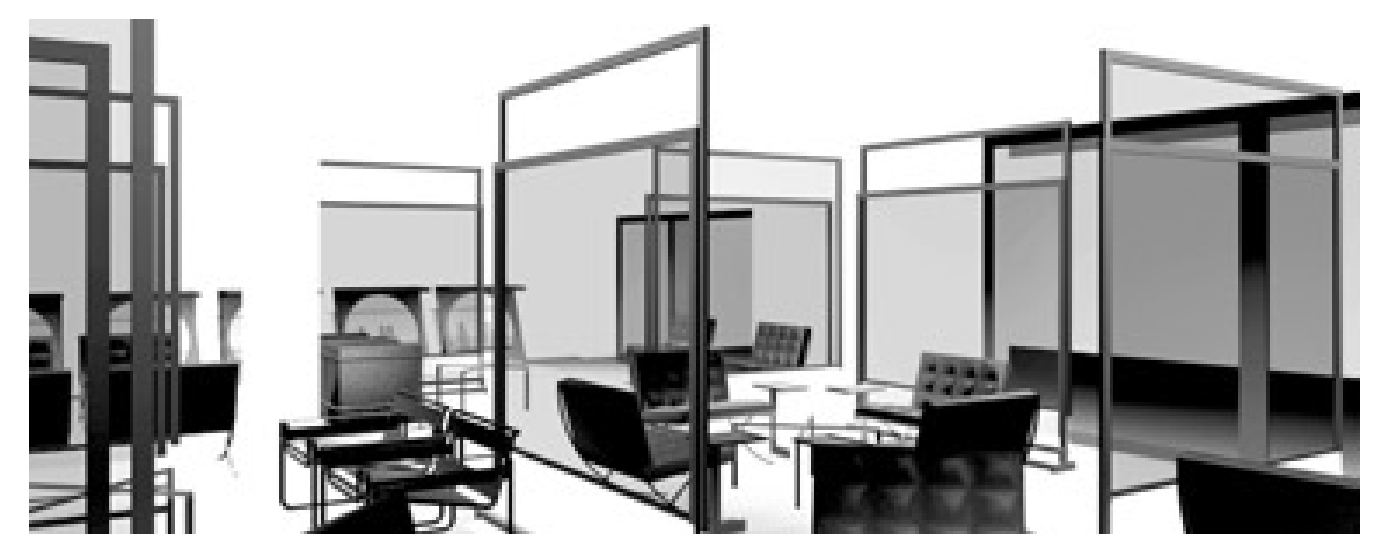

\title{
Salón del Vino C y T
}

El año 1999, a raíz del entusiasmo que provocó internet en las nuevas relaciones personales y comerciales, la Viña Concha y Toro convocó a cinco oficinas de arquitectura a un concurso que solicitaba crear un espacio con nuevos programas, y con el desafío de relacionar esta nueva oferta con el mundo de los vinos. Nuestra oficina se adjudicó el proyecto.

La primera intención de la propuesta busca relacionar la memoria, la comida, el vino y el evento. Por medio de un espacio flexible propusimos un programa asociado a las actitudes de ocio e interacción social, que surgen en las inauguraciones en galerías de arte como también en lugares que están asociados a los salones de un club, donde los encuentros se acompañan de aperitivos y pequeñas cosas para comer. Este concepto tenía como objetivo proponer un lugar social y múltiple, motivado por un programa variable que en todos los casos permite acceso a diversa información, y que de un modo sencillo puede programar en la memoria de los usuarios una asociación directa de los vinos con las comidas y la sociabilidad.

La segunda idea relaciona vino, objeto $y$ memoria colectiva. Con el fin de caracterizar este espacio flexible propusimos interpretar dos objetos comunes al vino, la barrica y la copa La estructura formal de las barricas de madera, donde los vinos tradicionalmente se guardan y maduran, fue interpretada asignándole diferentes funciones: cocina, barra y cava. Ellas ocupaban y escalaban este gran salón informático de sillones, mesas, libreros y computadores siendo ubicados en el borde del recinto, entre el interior y el exterior, articulando así las terrazas perimetrales con los distintos interiores.

El segundo objeto que utilizamos fue la copa de vino y el color que éste adquiere dependiendo de las distintas cepas. Esta idea fue interpretada por una serie de biombos móviles de vidrio, con un espesor interior, para contener líquidos de colores, que destacaban las siluetas de la gente y que teñían con colores amarillos y rojos los distintos lugares.

En esta propuesta espacial, que permite ver la totalidad del lugar como un solo salón de actividades cotidianas y sencillas de traspaso de información, quisimos proponer una nueva estrategia de mercado para la Viña Concha y Toro. El proyecto apuntó a crear un lugar de encuentros informales en torno al vino: un ciberwine, una biblioteca, un lugar para encontrar a otros. ARQ 

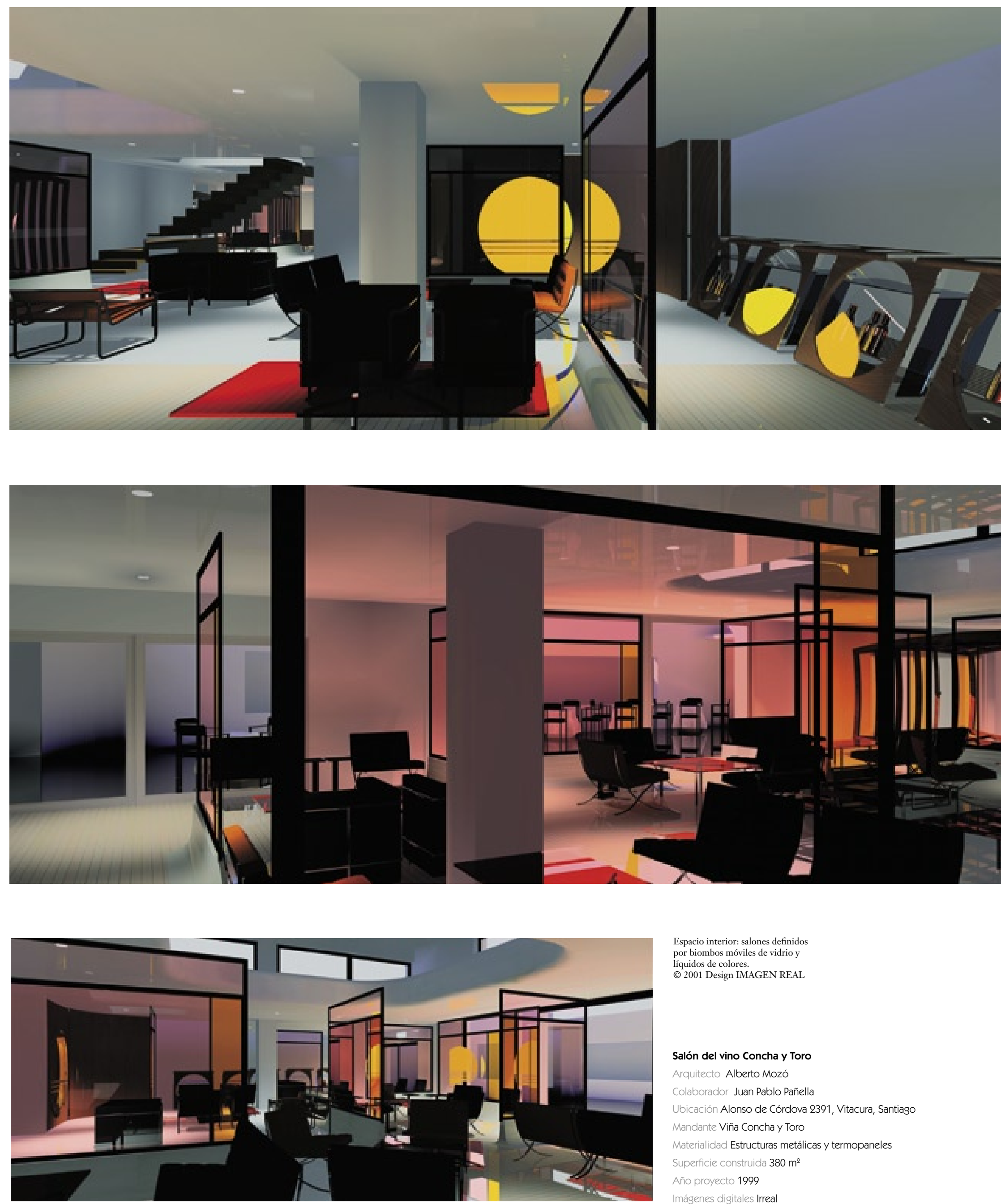

Espacio interior: salones definidos

por biombos móviles de vidrio y

(o) 2001 Design IMAGEN REAL

Salón del vino Concha y Toro

Arquitecto Alberto Mozó

Colaborador Juan Pablo Pañella

Ubicación Alonso de Córdova 2391, Vitacura, Santiago

Mandante Viña Concha y Toro

Materialidad Estructuras metálicas y termopaneles

Superficie construida $380 \mathrm{~m}^{2}$

Año proyecto 1999

Imágenes digitales Irreal 